\title{
THE CARDIOVASCULAR MARKET IN ROMANIA DURING 1998 - 2017 PERIOD - ANALYSIS AND EVOLUTION
}

\author{
MARIAN PANA ${ }^{1 \#}$, PETRU CRĂCIUN ${ }^{1 \#}$, CAMELIA NICOLAE $^{2 \#}$, ADRIANA-ELENA TĂEREL $^{3 *}$, \\ DUMITRU LUPULIASA ${ }^{1}$
}

${ }^{\text {I} P h a r m a c e u t i c a l ~ T e c h n o l o g y ~ a n d ~ B i o p h a r m a c y ~ D e p a r t m e n t, ~ F a c u l t y ~ o f ~ P h a r m a c y, ~ " C a r o l ~ D a v i l a " ~ U n i v e r s i t y ~ o f ~ M e d i c i n e ~}$ and Pharmacy, Bucharest, Romania

${ }^{2}$ Cardiology Department, Panduri Hospital, Bucharest, Romania

${ }^{3}$ Department of Pharmaceutical Management and Marketing, Faculty of Pharmacy, University of Medicine and Pharmacy

"Carol Davila", Bucharest, Romania

*corresponding author: adriana.taerel@yahoo.com

${ }^{*}$ Authors with equal contribution

Manuscript received: February 2019

\begin{abstract}
By all dimensions of analysis: units, DOT and values, the cardiovascular market has grown significantly over the last twenty years. However, it is still questionable if this development is enough, as cardiovascular diseases account for the most important mortality factor in Romania. Concerning therapeutic groups, of used cardiovascular drugs the biggest share in days of treatment belongs to C9 (inhibitors of the renin-angiotensin system), followed at certain distance by C10 (anti-atheroma agents and lipid regulators), C1 (cardiac therapy), C7 (beta-blocking agents), C8 (calcium antagonists) and C3 (diuretics). Regarding channels, retail channel accounts for dispensing almost all cardiovascular drugs. By administration route, oral solid forms are by far the most used form. Taking into consideration the product type, generic medicines are dominating in volume, while original medicines leads in value. Concerning market layers, volume and value of cardiovascular drugs are balanced between the 3 layers, while almost $2 / 3$ of the population stays in the $3^{\text {rd }}$ layer, which raises questions about the treatment accessibility in small cities and villages. Regarding INNs, there is a significant dynamic over the time; currently the most used are metoprolol, indapamide and atorvastatin.
\end{abstract}

\section{Rezumat}

Medicația cardiovasculară s-a dezvoltat susținut în ultimii douăzeci de ani în toate dimensiunile analizate: volum, zile de tratament, valoare. Pe grupe terapeutice, ca număr de zile de tratament, pe primul loc se situează inhibitorii sistemului reninăangiotensină (C9), urmați de agenți anti-aterom și regulatoare lipidice (C10), terapia cardiacă (C1), beta-blocante (C7), antagoniști de calciu (C8) și diuretice (C3). Pe canale, farmacia de retail eliberează medicația cardiovasculară aproape în totalitate. În ceea ce privește calea de administrare, există o majoritate covârşitoare pentru formele orale solide. Ca tip de produse, medicamentele generice ocupă cea mai mare parte ca volum, iar medicamentele originale ca valoare. Pe straturi, cele 3 straturi sunt comparabile ca volum și valoare, dar ținând cont că stratul 3 conține aproape două treimi din populație, ne putem întreba dacă accesibilitatea la tratament cardiovascular este bună la nivelul orașelor mici şi al satelor. Ca DCI-uri, există o dinamică semnificativă de-a lungul timpului; cele mai folosite în momentul de față sunt metoprolol, indapamid și atorvastatină.

Keywords: ATC, cardiovascular medication, units, DOT, market layer, INN, administration route

\section{Introduction}

Cardiovascular diseases are one of the four major non-communicable diseases (NCDs), which are the leading causes of death worldwide, according to World Health Organization (WHO) report from 2018 [14]. In spite of decreases in mortality rates in many countries, cardiovascular diseases are responsible for 17.9 million deaths (representing $44 \%$ of all NCD deaths and $31 \%$ of global deaths) [3, 10, 14]. Consequently, they represent a global burden to the health-care system and one major cause of hospitalization and disabilitation among elderly and adults. For this reason, six medicines found on the 10 essential NCD medicines list are used for the secondary cardiovascular treatment: angiotensin-converting enzyme inhibitors, aspirin, beta-blockers, long-acting calcium channel blockers, statins, thiazide diuretics [13, 15]. Taking into account that cardiovascular diseases is one of the major mortality factor in Romania [1], the evolution of the cardiovascular drugs market has shown a sustained development for the last twenty years. The WHO country profile report has revealed that cardiovascular diseases are estimated to account for $56 \%$ of all deaths from Romania in 2016 [14]. 


\section{Materials and Methods}

We performed a retrospective study based on the information extracted from Pharma \& Hospital Report (during a period of nineteen years, from 1998 to 2017) [11], a comprehensive pharmaceutical data issued monthly by Cegedim starting with 1996. Pharma \& Hospital Report represents a statistical estimation of the medicines consumption at national level, using primary data from a panel of pharmacies.

Analysis has performed taking into account the following variables: Anatomical Therapeutic Chemical (ATC) groups (volume, DOT); channel; market layer; product type; administration route; International Nonproprietary Name (INN).

We have analysed the evolution of the cardiovascular market based on the ATC level 1 and 2 therapeutic groups over the period 1998 - 2017, separated in two decades, and compared the results obtained for 1998, 2007 and 2017 using as variables: volume, DOT and value. After that, we have carried out an analysis using units and values as variables in order to observe the differences between retail and hospital channel. Three market layers were defined and the penetration rate of cardiovascular drugs was established for 2007 and 2017. Furthermore, we have analysed the trends on the Romanian market taking into account the administration route and the product type (the distribution of original medicines compared with generic ones). In order to have a better perspective over the therapeutic developments and pharmaceutical evolution, the hierarchy of the most prescribed active

substances was presented. As statins are being recommended as the first-line drugs for different cardiovascular diseases $[6,7]$, they have been analysed through product type, market layer and top INN.

\section{Methodological specifications}

ATC $=$ Anatomical Therapeutic Chemical $=5$-level classification system developed and updated yearly by the WHO Collaborating Centre for Drug Statistics Methodology; $\mathrm{C}=$ cardiovascular; Units = number of units (packs); DOT (Days of Treatment) = it was calculated based on the DDD (Defined Daily Dose), updated yearly by the WHO Collaborating Centre for Drug Statistics Methodology; MSP = Manufacturer Selling Price; MS = Market Share; Channel; Market layer; Product type $=$ original (innovative) and generic medicines; Prescription drugs $=\mathrm{Rx}$ medicines (dispensed with a medical prescription); OTC drugs = OTC medicines (dispensed without a medical prescription); Administration route; INN = International Nonproprietary Name; RON = Lei; EUR = Euro; Millions.

\section{Results and Discussion}

Group C (cardiovascular) - total

As a total, the cardiovascular market has registered a significant growth (Table I), especially in the first decade (1998 - 2007): more than double in volume, more than quadruple in days of treatment and much more in value*. The next decade (2007 - 2017) shows also growth but rather in a stabilization pattern, as the market becomes more mature and offer and demand are closer than in the previous period.

Table I

ATC1 - Cardiovascular System

\begin{tabular}{|l|c|c|c|c|c|}
\hline C (Cardiovascular System) & $\mathbf{1 9 9 8}$ & $\mathbf{2 0 0 7}$ & $\mathbf{2 0 0 7}$ vs 1998 & $\mathbf{2 0 1 7}$ & $\mathbf{2 0 1 7}$ vs 2007 \\
\hline Units (millions) & 43.27 & 95.00 & $119.6 \%$ & 135.63 & $42.8 \%$ \\
\hline DOTs (millions) & 431.40 & $1,721.20$ & $299.0 \%$ & $3,165.70$ & $83.9 \%$ \\
\hline MSP Value (mill. RON*) & 37.38 & $1,088.20$ & $2,811.2 \%$ & $1,831.80$ & $68.3 \%$ \\
\hline DOT/unit & 9.97 & 18.12 & $81.7 \%$ & 23.34 & $28.8 \%$ \\
\hline RON/unit & 0.86 & 11.45 & $1,226.0 \%$ & 13.51 & $17.9 \%$ \\
\hline RON/DOT & 0.09 & 0.63 & $629.7 \%$ & 0.58 & $-8.5 \%$ \\
\hline
\end{tabular}

*The RON value in 1998 is somehow misleading, even it was made at the rate $10,000 \mathrm{ROL}=1 \mathrm{RON}$. The denomination (2005) does not contain long-time variation in value/purchasing power of the local currency

Also growth is displayed for the calculated averages: DOT/unit increase from 9.97 in 1998 to 23.34 in 2017 (change toward majority chronical treatment, 30 days a pack); RON/unit increase from 0.86 in 1998 to 13.51 in 2017 (we must remember that in 1998 the vast majority of cardiovascular consumption was made by domestic relatively old products, which additionally were at fix price in a period with very high devaluation/inflation); RON/DOT increase from 0.09 in 1998 to 0.58 in 2017 (with a notable exception of $8.5 \%$ decrease between $2007-2017$, due to the administrative price reduction).

ATC2 therapeutic groups

The cardiovascular market based on the ATC level 2 $[8,18,20]$ therapeutic groups shows the following trends in units (Table II): a significant growth for the groups C3 (diuretics), C7 (beta-blocking agents), C9 (inhibitors of the renin-angiotensin system) and C10 (anti-atheroma agents and lipid regulators); a moderate growth for the groups $\mathrm{C} 4$ (cerebral and peripheral vasotherapeutics) and C5 (antivaricosis/antihaemorrhoidal preparations); a relative stagnation of $\mathrm{C} 1$ (cardiac therapy), C6 (other cardiovascular products) and C8 (calcium antagonists); a decrease of C2 (antihypertensives).

From the statistical point of view the sample sizes are relative small and in this working hypotheses we found that the assumptions of normality and sphericity doesn't check for applying the method of analysis of variance (ANOVA) with repeated measures. Thereby, 
the p-values were calculated based on Friedman test, a non-parametric test, equivalent to repeated measures ANOVA. When it was necessary, we continued the statistical analysis with the Nemenyi post hoc test to compare all the pairs. For the statistical analysis of

a cardiovascular system by ATC2 groups - units (Table II) we applied Friedmann test to find if there were significant differences between the studied years. We obtained a p-value $=0.009331(<0.05)$ which sustain the differences between time groups.

Table II

Cardiovascular by ATC2 groups - units

\begin{tabular}{|l|c|c|c|c|c|c|}
\hline \multicolumn{1}{|c|}{$\begin{array}{l}\text { ATC1 } \\
\text { ATC2 }\end{array}$} & $\begin{array}{c}\text { Units } \\
\mathbf{1 9 9 8} \\
\text { Millions }\end{array}$ & $\begin{array}{c}\text { as } \% \\
\text { of total } \\
\text { C }\end{array}$ & $\begin{array}{c}\text { Units } \\
\mathbf{2 0 0 7} \\
\text { Millions }\end{array}$ & $\begin{array}{c}\text { as \% } \\
\text { of total } \\
\text { C }\end{array}$ & $\begin{array}{c}\text { Units } \\
\mathbf{2 0 1 7} \\
\text { Millions }\end{array}$ & $\begin{array}{c}\text { as \% } \\
\text { of total } \\
\text { C }\end{array}$ \\
\hline C (CARDIOVASCULAR SYSTEM) & $\mathbf{4 3 . 2 7}$ & $\mathbf{1 0 0 . 0 \%}$ & $\mathbf{9 5 . 0 0}$ & $\mathbf{1 0 0 . 0 \%}$ & $\mathbf{1 3 5 . 6 3}$ & $\mathbf{1 0 0 . 0 \%}$ \\
\hline C1 (CARDIAC THERAPY) & 10.72 & $24.8 \%$ & 12.25 & $12.9 \%$ & 12.36 & $9.1 \%$ \\
\hline C2 (ANTIHYPERTENSIVES) & 3.44 & $8.0 \%$ & 0.65 & $0.7 \%$ & 1.76 & $1.3 \%$ \\
\hline C3 (DIURETICS) & 2.17 & $5.0 \%$ & 11.74 & $12.4 \%$ & 17.16 & $12.7 \%$ \\
\hline C4 (CEREBRAL AND PERIPHERAL VASOTHERAPY) & 6.16 & $14.2 \%$ & 11.29 & $11.9 \%$ & 8.25 & $6.1 \%$ \\
\hline C5 (ANTIVARICOSIS/ANTI-HAEMORRHOIDAL PREP) & 5.52 & $12.8 \%$ & 7.56 & $8.0 \%$ & 9.93 & $7.3 \%$ \\
\hline C6 (OTHER CARDIOVASCULAR PRODUCTS) & 3.33 & $7.7 \%$ & 2.57 & $2.7 \%$ & 2.58 & $1.9 \%$ \\
\hline C7 (BETA-BLOCKING AGENTS) & 2.80 & $6.5 \%$ & 13.25 & $13.9 \%$ & 25.85 & $19.1 \%$ \\
\hline C8 (CALCIUM ANTAGONISTS) & 6.09 & $14.1 \%$ & 5.67 & $6.0 \%$ & 7.13 & $5.3 \%$ \\
\hline $\begin{array}{l}\text { C9 (AGENTS ACTING ON THE RENIN-ANGIOTENSIN } \\
\text { SYSTEM) }\end{array}$ & 2.76 & $6.4 \%$ & 23.09 & $24.3 \%$ & 33.65 & $24.8 \%$ \\
\hline C10 (LIPID-REGULATING/ANTI-ATHEROMA PREP) & 0.28 & $0.6 \%$ & 6.94 & $7.3 \%$ & 16.54 & $12.2 \%$ \\
\hline C11 (CARDIOVASCULAR MULTITHERAPY COMB PROD) & 0.00 & $0.0 \%$ & 0.00 & $0.0 \%$ & 0.42 & $0.3 \%$ \\
\hline
\end{tabular}

In order to evaluate if each group are different from another one, we applied a post hoc test and we find a significative difference only between the group studied in 1998 and the one studied in 2017 with a $\mathrm{p}$ value $=0.011(<0.05)$. The other of $p$-values were not implying significant differences (Figures 1 and 2).

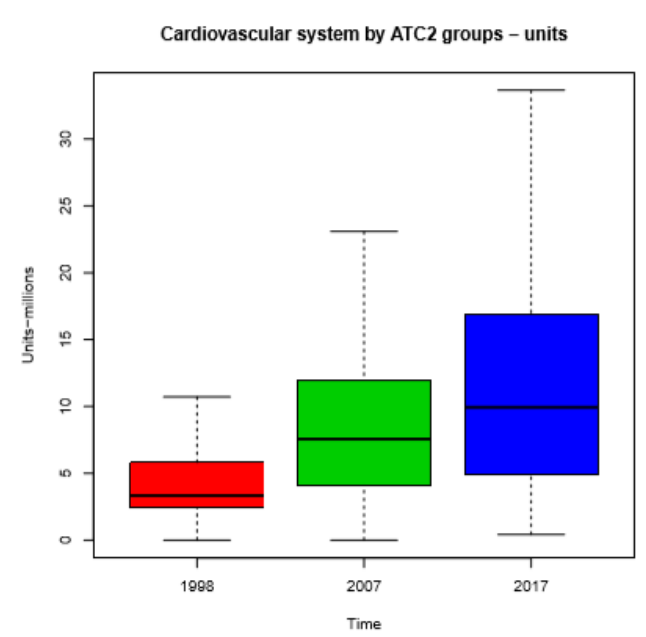

Figure 1.

Boxplot with three samples of every studied year for the comparison of millions of units of the cardiovascular market

Similar trends are registered in days of treatment (Table III), with the following exceptions: C1 (cardiac therapy) and C8 (calcium antagonists) have rather significant growth in DOTs compared with relative stagnation in units, as a result of consistent increase of DOT/unit.
Line chart of the growth curve for each of the eleven cardio system

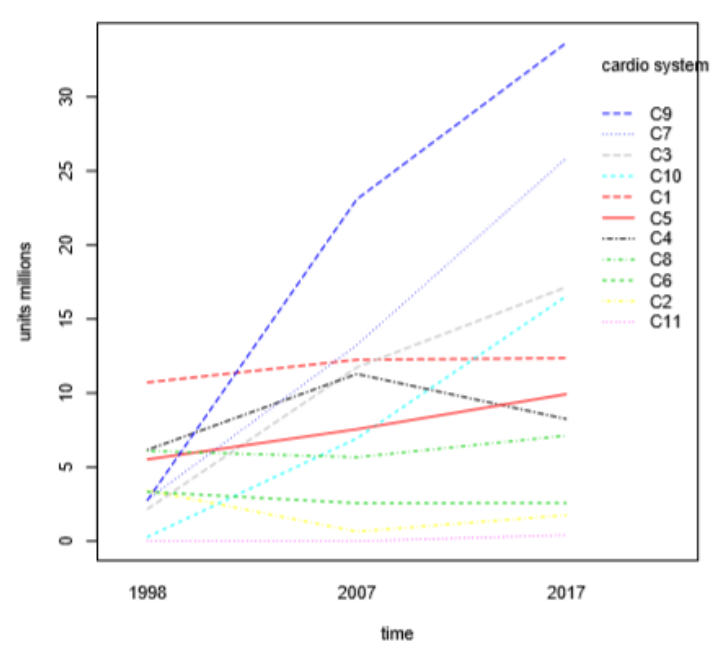

Figure 2.

A line chart of a cardio system displaying the increase and decrease of each therapeutic group

One of the initiatives of The European Society of Cardiology was the implementation of EUROSPIRE project, based on collecting data from hospital patients with coronary heart diseases. The EUROSPIRE IV survey, conducted in 24 European countries (2015 2016, Romania being one of them) showed that anti-platelets were the most used drugs (93.8\%), followed by statins, with a large increase in prescribing $(85.7 \%)$, then $\beta$-blockers $(82.6 \%)$, and angiotensinconverting enzyme inhibitors (75.1\%), observing a growth from the previous EUROSPIRE III survey results $(91 \% ; 80 \% ; 78 \%$ and $71 \%$, calcium channel blockers being mentioned as representing 25\%). Consequently, it can be identified a significant growth, 
FARMACIA, 2019, Vol. 67, 5

similar with the situation showed in Table II for groups $\mathrm{C} 7, \mathrm{C} 9$ and $\mathrm{C} 10$, variations coming from

differences between countries in national medical practice, lifestyles, risk factors for CVD [3, 4]

Table III

Cardiovascular by ATC2 groups - DOTs

\begin{tabular}{|l|c|c|c|c|c|c|}
\hline \multicolumn{1}{|c|}{$\begin{array}{l}\text { ATC1 } \\
\text { ATC2 }\end{array}$} & $\begin{array}{c}\text { DOT } \\
\mathbf{1 9 9 8} \\
\text { Millions }\end{array}$ & $\begin{array}{c}\text { as } \% \\
\text { of total } \\
\text { C }\end{array}$ & $\begin{array}{c}\text { DOT } \\
\mathbf{2 0 0 7} \\
\text { Millions }\end{array}$ & $\begin{array}{c}\text { as } \% \\
\text { of total } \\
\text { C }\end{array}$ & $\begin{array}{c}\text { DOT } \\
\mathbf{2 0 1 7} \\
\text { Millions }\end{array}$ & $\begin{array}{c}\text { as } \% \\
\text { of total } \\
\text { C }\end{array}$ \\
\hline C (CARDIOVASCULAR SYSTEM) & $\mathbf{4 3 1 . 4}$ & $\mathbf{1 0 0 . 0 \%}$ & $\mathbf{1 , 7 2 1 . 2}$ & $\mathbf{1 0 0 . 0 \%}$ & $\mathbf{3 , 1 6 5 . 7}$ & $\mathbf{1 0 0 . 0 \%}$ \\
\hline C1 (CARDIAC THERAPY) & 121.3 & $28.1 \%$ & 305.3 & $17.7 \%$ & 370.5 & $11.7 \%$ \\
\hline C2 (ANTIHYPERTENSIVES) & 41.4 & $9.6 \%$ & 15.3 & $0.9 \%$ & 17.3 & $0.5 \%$ \\
\hline C3 (DIURETICS) & 55.3 & $12.8 \%$ & 194.2 & $11.3 \%$ & 267.8 & $8.5 \%$ \\
\hline C4 (CEREBRAL AND PERIPHERAL VASOTHERAPEUTICS) & 32.6 & $7.6 \%$ & 107.6 & $6.3 \%$ & 83.6 & $2.6 \%$ \\
\hline $\begin{array}{l}\text { C5 (ANTIVARICOSIS/ANTI-HAEMORRHOIDAL } \\
\text { PREPARATIONS) }\end{array}$ & 5.5 & $1.3 \%$ & 7.6 & $0.4 \%$ & 9.9 & $0.3 \%$ \\
\hline C6 (OTHER CARDIOVASCULAR PRODUCTS) & 3.3 & $0.8 \%$ & 2.6 & $0.2 \%$ & 2.6 & $0.1 \%$ \\
\hline C7 (BETA-BLOCKING AGENTS) & 33.4 & $7.7 \%$ & 164.9 & $9.6 \%$ & 370.9 & $11.7 \%$ \\
\hline C8 (CALCIUM ANTAGONISTS) & 87.2 & $20.2 \%$ & 169.9 & $9.9 \%$ & 300.4 & $9.5 \%$ \\
\hline C9 (AGENTS ACTING ON THE RENIN-ANGIOTENSIN SYSTEM) & 47.1 & $10.9 \%$ & 616.7 & $35.8 \%$ & $1,303.6$ & $41.2 \%$ \\
\hline C10 (LIPID-REGULATING/ANTI-ATHEROMA PREPARATIONS) & 4.3 & $1.0 \%$ & 137.2 & $8.0 \%$ & 438.7 & $13.9 \%$ \\
\hline C11 (CARDIOVASCULAR MULTITHERAPY COMB PROD) & 0.0 & $0.0 \%$ & 0.0 & $0.0 \%$ & 0.4 & $0.0 \%$ \\
\hline
\end{tabular}

Table IV

Cardiovascular by Channel

\begin{tabular}{|l|c|c|c|c|c|c|c|c|c|c|}
\hline \multicolumn{1}{|c|}{$\begin{array}{c}\text { ATC1 } \\
\text { CHANNEL }\end{array}$} & $\begin{array}{c}\text { Units } \\
\mathbf{1 9 9 8} \\
\text { Mill. }\end{array}$ & $\begin{array}{c}\text { as \% } \\
\text { of total } \\
\mathbf{C}\end{array}$ & $\begin{array}{c}\text { Units } \\
\mathbf{2 0 0 7} \\
\text { Mill. }\end{array}$ & $\begin{array}{c}\text { as \% } \\
\text { of total } \\
\mathbf{C}\end{array}$ & $\begin{array}{c}\text { Units } \\
\mathbf{2 0 1 7} \\
\text { Mill. }\end{array}$ & $\begin{array}{c}\text { as \% } \\
\text { of total } \\
\mathbf{C}\end{array}$ & $\begin{array}{c}\text { Values } \\
\mathbf{2 0 0 7} \\
\text { Mill. } \\
\text { RON }\end{array}$ & $\begin{array}{c}\text { as \% } \\
\text { of total } \\
\text { C }\end{array}$ & $\begin{array}{c}\text { Values } \\
\mathbf{2 0 1 7} \\
\text { Mill. } \\
\text { RON }\end{array}$ & $\begin{array}{c}\text { as \% } \\
\text { of total } \\
\text { C }\end{array}$ \\
\hline $\begin{array}{l}\text { C (CARDIO } \\
\text { SYSTEM) }\end{array}$ & $\mathbf{4 3 . 3}$ & $100.0 \%$ & $\mathbf{9 5 . 0}$ & $100.0 \%$ & $\mathbf{1 3 5 . 6}$ & $100.0 \%$ & $\mathbf{1 , 0 8 8 . 2}$ & $100.0 \%$ & $\mathbf{1 , 8 3 1 . 8}$ & $100.0 \%$ \\
\hline Retail pharmacy & 38.9 & $89.8 \%$ & 93.0 & $97.9 \%$ & 133.5 & $98.5 \%$ & $1,069.4$ & $98.3 \%$ & $1,801.8$ & $98.4 \%$ \\
\hline Hospital pharmacy & 4.4 & $10.2 \%$ & 2.0 & $2.1 \%$ & 2.1 & $1.5 \%$ & 18.8 & $1.7 \%$ & 30.0 & $1.6 \%$ \\
\hline
\end{tabular}

\section{Channel}

As shown in the Table IV, almost all $(98.5 \%$ in 2017) of the cardiovascular diseases treatments are dispensed in the retail channel (ambulatory area) which means community pharmacies, while hospitals treats cardiovascular patients in acute status or with non-drug interventions. $s$.

Volume evolution reveals that an increased number of patients have been treated with cardiovascular medicines; while value analysis showed that this market has grown significantly (although maybe not enough, given the price reduction) in the last ten year. As the retail channel practically equals all chronic cardiovascular treatment and cardiovascular

diseases as the first health problem in Romania, we believe that an increased importance is needed in the future, both in better treatment and in proper functioning of the retail channel.

Market layer

"Market layer" represents a purchasing behaviour attribute, derived from demographic criteria [16]; three "market layers" were defined: Bucharest and big cities (university cities or $>250,000$ inhabitants); Medium cities (50,000 - 250,000 inhabitants); Small cities $(<50,000$ inhabitants) and rural area. As this attribute was not available in 1998, we will see only last decade from this perspective (Table V).

Table V

Cardiovascular by Market layer

\begin{tabular}{|l|c|c|c|c|c|c|c|c|c|}
\hline $\begin{array}{c}\text { ATC1 } \\
\text { MARKET } \\
\text { LAYER }\end{array}$ & $\begin{array}{c}\text { Popu- } \\
\text { lation } \\
\mathbf{\%}\end{array}$ & $\begin{array}{c}\text { Units } \\
\mathbf{2 0 0 7} \\
\text { Mill. }\end{array}$ & $\begin{array}{c}\text { as \% } \\
\text { of total } \\
\text { C }\end{array}$ & $\begin{array}{c}\text { Units } \\
\mathbf{2 0 1 7} \\
\text { Mill. }\end{array}$ & $\begin{array}{c}\text { as \% } \\
\text { of total } \\
\text { C }\end{array}$ & $\begin{array}{c}\text { Values } \\
\mathbf{2 0 0 7} \\
\text { Mill.RON }\end{array}$ & $\begin{array}{c}\text { as \% } \\
\text { of total } \\
\text { C }\end{array}$ & $\begin{array}{c}\text { Values } \\
\mathbf{2 0 1 7} \\
\text { Mill.RON }\end{array}$ & $\begin{array}{c}\text { as \% } \\
\text { of total } \\
\text { C }\end{array}$ \\
\hline C (CARDIO SYSTEM) & $\mathbf{1 0 0 . 0 \%}$ & $\mathbf{9 5 . 0}$ & $\mathbf{1 0 0 . 0 \%}$ & $\mathbf{1 3 5 . 6}$ & $\mathbf{1 0 0 . 0 \%}$ & $\mathbf{1 , 0 8 8 . 2}$ & $\mathbf{1 0 0 . 0 \%}$ & $\mathbf{1 , 8 3 1 . 8}$ & $\mathbf{1 0 0 . 0 \%}$ \\
\hline Important cities & $19.3 \%$ & 42.1 & $44.3 \%$ & 48.2 & $35.5 \%$ & 526.6 & $48.4 \%$ & 696.1 & $38.0 \%$ \\
\hline Medium-size cities & $16.1 \%$ & 24.0 & $25.3 \%$ & 36.1 & $26.6 \%$ & 270.2 & $24.8 \%$ & 501.5 & $27.4 \%$ \\
\hline Small cities \& villages & $64.6 \%$ & 28.9 & $30.4 \%$ & 51.3 & $37.8 \%$ & 291.4 & $26.8 \%$ & 634.2 & $34.6 \%$ \\
\hline
\end{tabular}

The penetration rate is significant in all three layers. However, although we assume that purchasing habits in important/medium-size cities include the treatment of certain patients from small cities and rural (parents, grandparents, other relatives), we can see a certain disbalance between important and medium-size cities, 
on one hand, and small cities \& villages, on the other hand. This disbalance is sizeable in both treatment volume $\left(37.8 \%\right.$ units vs $64.6 \%$ population in the $3^{\text {rd }}$ layer) and value $(34.6 \%$ value vs $37.8 \%$ volume in the $3^{\text {rd }}$ layer, compared with $38.0 \%$ value vs $35.5 \%$ volume in the $1^{\text {st }}$ layer).

Product type

According to patent ownership, original products (only branded) are the originators of the patent (Table VI), during and after protection, while generic medicines (branded or not) are marketed after the originators' patent protection have expired $[17,19]$.

Table VI

Cardiovascular by Product type

\begin{tabular}{|l|c|c|c|c|c|c|c|c|c|c|}
\hline $\begin{array}{c}\text { ATC1 } \\
\text { STATUS } \\
\text { PROD TYPE }\end{array}$ & $\begin{array}{c}\text { Units } \\
\mathbf{1 9 9 8} \\
\text { Mill. }\end{array}$ & $\begin{array}{c}\text { \% as } \\
\text { of total } \\
\text { C }\end{array}$ & $\begin{array}{c}\text { Units } \\
\mathbf{2 0 0 7} \\
\text { Mill. }\end{array}$ & $\begin{array}{c}\text { \% as } \\
\text { of total } \\
\text { C }\end{array}$ & $\begin{array}{c}\text { Units } \\
\mathbf{2 0 1 7} \\
\text { Mill. }\end{array}$ & $\begin{array}{c}\text { \% as } \\
\text { of total } \\
\text { C }\end{array}$ & $\begin{array}{c}\text { Values } \\
\mathbf{2 0 0 7} \\
\text { Mill. } \\
\text { RON }\end{array}$ & $\begin{array}{c}\text { \% as } \\
\text { of total } \\
\text { C }\end{array}$ & $\begin{array}{c}\text { Values } \\
\mathbf{2 0 1 7} \\
\text { Mill. } \\
\text { RON }\end{array}$ & $\begin{array}{c}\% \text { as } \\
\text { of total } \\
\text { C }\end{array}$ \\
\hline C (CARDIO SYSTEM) & $\mathbf{4 3 . 3}$ & $\mathbf{1 0 0 . 0 \%}$ & $\mathbf{9 5 . 0}$ & $\mathbf{1 0 0 . 0 \%}$ & $\mathbf{1 3 5 . 6}$ & $\mathbf{1 0 0 . 0 \%}$ & $\mathbf{1 , 0 8 8 . 2}$ & $\mathbf{1 0 0 . 0 \%}$ & $\mathbf{1 , 8 3 1 . 8}$ & $\mathbf{1 0 0 . 0 \%}$ \\
\hline Rx drugs & $\mathbf{3 7 . 3}$ & $\mathbf{8 6 . 1 \%}$ & $\mathbf{8 8 . 4}$ & $\mathbf{9 3 . 1 \%}$ & $\mathbf{1 2 7 . 2}$ & $\mathbf{9 3 . 8 \%}$ & $\mathbf{1 , 0 4 1 . 3}$ & $\mathbf{9 5 . 7 \%}$ & $\mathbf{1 , 6 6 7 . 6}$ & $\mathbf{9 1 . 0 \%}$ \\
\hline Original brands & 2.8 & $6.5 \%$ & 25.8 & $27.2 \%$ & 49.1 & $36.2 \%$ & 593.4 & $54.5 \%$ & 988.5 & $54.0 \%$ \\
\hline Branded generics & 20.5 & $47.3 \%$ & 43.0 & $45.3 \%$ & 67.6 & $49.9 \%$ & 378.2 & $34.8 \%$ & 630.4 & $34.4 \%$ \\
\hline Un-branded generics & 14.0 & $32.3 \%$ & 19.6 & $20.6 \%$ & 10.5 & $7.7 \%$ & 69.8 & $6.4 \%$ & 48.8 & $2.7 \%$ \\
\hline OTC drugs & $\mathbf{6 . 0}$ & $\mathbf{1 3 . 9 \%}$ & $\mathbf{6 . 6}$ & $\mathbf{6 . 9 \%}$ & $\mathbf{8 . 4}$ & $\mathbf{6 . 2 \%}$ & $\mathbf{4 6 . 9}$ & $\mathbf{4 . 3 \%}$ & $\mathbf{1 6 4 . 2}$ & $\mathbf{9 . 0 \%}$ \\
\hline
\end{tabular}

As cardiovascular drugs are mainly $\mathrm{Rx}$, the table above displays that this market is dominated by generic medicines in volume, respectively by original medicines in value.

This was possible due to continuous increase of original drugs, in units the evolution was from $6.5 \%$ in 1998 to $27.2 \%$ in 2007 and $36.2 \%$ in 2017 , while the generics have decreased accordingly; between

generics, we may note the significant decrease of un-branded drugs (from $32.3 \%$ in 1998 to $20.6 \%$ in 2007 and $7.7 \%$ in 2017), while branded drugs share was relative constant.

Administration route

According to the administration route [9], there can be noticed changes in the way the treatment is administered in time (Table VII).

Table VII

Cardiovascular by Administration route

\begin{tabular}{|c|c|c|c|c|c|}
\hline $\begin{array}{c}\text { ATC1 } \\
\text { ADMIN ROUTE }\end{array}$ & $\begin{array}{c}\text { Units } \\
1998 \\
\text { Millions }\end{array}$ & $\begin{array}{c}\text { Units } \\
2007 \\
\text { Millions }\end{array}$ & $\begin{array}{c}\text { Units } \\
2017 \\
\text { Millions }\end{array}$ & $\begin{array}{c}\text { Values MSP } \\
2007 \\
\text { RON } \\
\text { Millions }\end{array}$ & $\begin{array}{c}\text { Values MSP } \\
2017 \\
\text { RON } \\
\text { Millions }\end{array}$ \\
\hline C (CARDIOVASCULAR SYSTEM) & 43.3 & 95.0 & 135.6 & $1,088.2$ & $1,831.8$ \\
\hline infusion (i.v.) & 0.1 & 0.1 & 0.1 & 2.2 & 17.6 \\
\hline inhalation & 0.0 & 0.0 & 0.1 & 0.4 & 0.5 \\
\hline injectable & 1.9 & 1.1 & 1.5 & 4.0 & 12.7 \\
\hline oral liquid & 1.3 & 0.9 & 0.1 & 9.5 & 2.3 \\
\hline oral solid & 35.7 & 88.9 & 129.9 & $1,051.8$ & $1,730.7$ \\
\hline rectal & 2.2 & 1.4 & 1.2 & 3.8 & 16.2 \\
\hline topical & 2.0 & 2.7 & 2.6 & 15.6 & 51.2 \\
\hline transdermal & 0.0 & 0.0 & 0.1 & 0.8 & 0.7 \\
\hline
\end{tabular}

From Table VII, oral solid pharmaceutical forms are exceeding by far other formulations, both in volume and value. Similar, for the statistical analysis of the cardiovascular system by administration route with ATC1 groups - units (Table VII) we applied the Friedmann test in order to find if there were significant differences between the studied years in relation with administration route. We obtained a pvalue $=0.8574(>0.05)$ which revealed no differences between time groups (Figures 3 and 4 ).
Friedmann test was also applied for the statistical analysis of a cardiovascular system by administration route with MSP RON Millions values (Table VII) in order to find if there are significant differences between the studied years in relation with the administration route for financial cardiovascular market. We obtain p-value $=0.1573(>0.05)$, so we have no differences between time groups (Figures 5 and 6). 


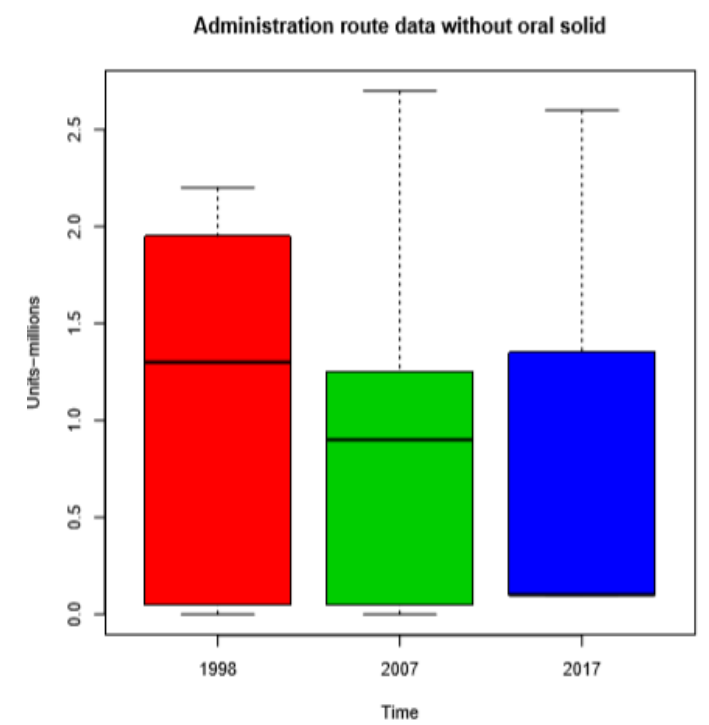

Figure 3.

Boxplot with three samples for every studied year for a comparation of units millions in relation to the administration route
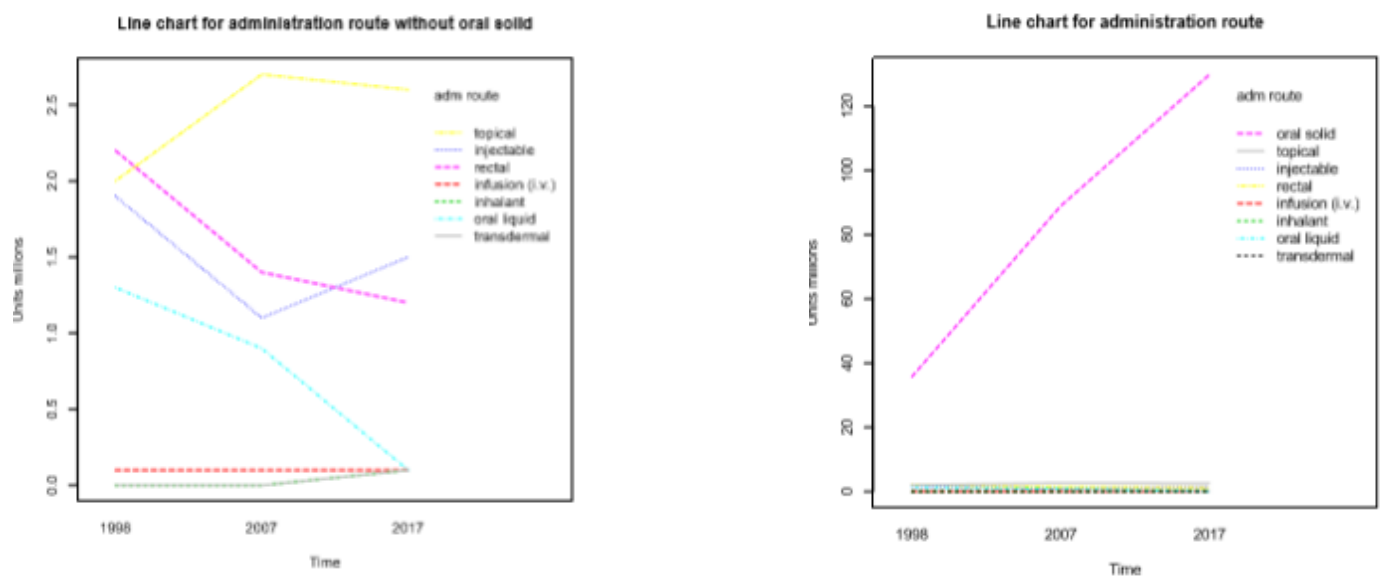

Figure 4.

A line chart of the cardiovascular market (units millions) which is displaying the increase and decrease for every administration route

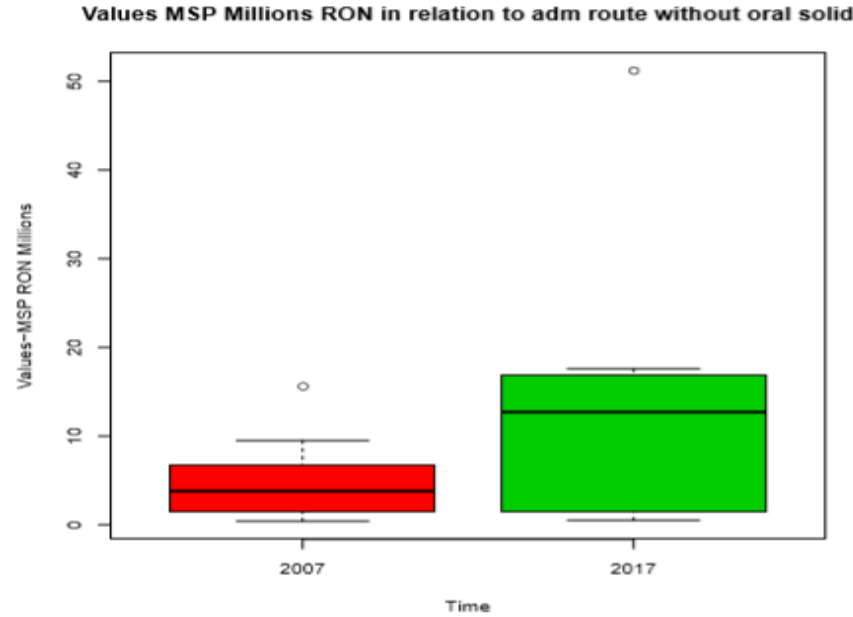

Figure 5.

Boxplot with two samples for every studied year for a comparation of financial market (millions RON) in relation with the administration route 

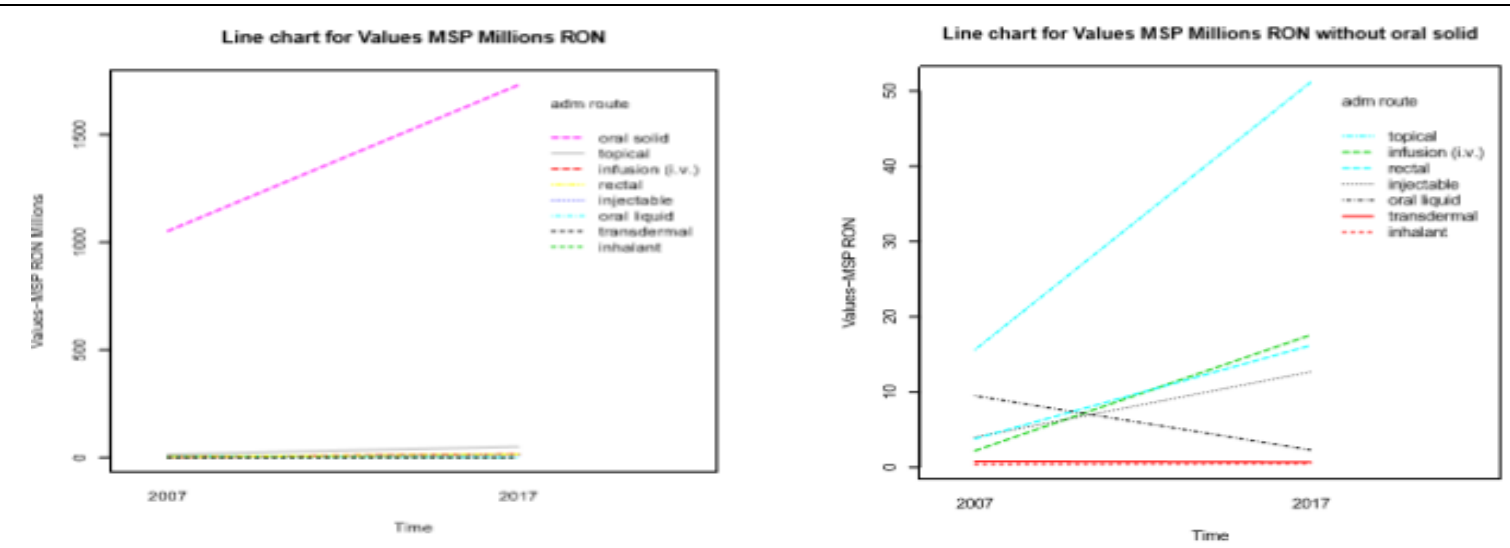

Figure 6.

A line chart of the financial cardiovascular market (millions RON) which is displaying the increase and decrease for every administration route

\section{INNS}

Regarding INNs [20], the performed analysis is rather difficult and question of relevance may arise; we have preferred a synthetic view (Table VIII) of the Top 10 INNs in 1998, 2007 and 2017, for the understanding of the therapeutic developments and pharmaceutical evolution.
We can notice that the first 3 INNs [20] in 2017 (metoprololum, indapamidum and atorvastatinum) had modest positions or did not exist in 1998. Also, the use of typical ACE inhibitors has declined: captoprilum, ranked $2^{\text {nd }}$ in 1998 become $6^{\text {th }}$ in 2007 and out of top 10 in 2017, while enalaprilum, ranked $3^{\text {rd }}$ in 1998 become $1^{\text {st }}$ in 2007 but ranks $4^{\text {th }}$ in 2017.

Table VIII

Cardiovascular by Top 10 INNs

\begin{tabular}{|c|c|c|c|c|c|c|}
\hline \multirow{2}{*}{ Rank } & \multicolumn{2}{|l|}{1998} & \multicolumn{2}{|l|}{2007} & \multicolumn{2}{|c|}{2017} \\
\hline & INN & $\%$ volume & INN & $\%$ volume & INN & \% volume \\
\hline 1 & acidum asparticum $\mathrm{K}+\mathrm{Mg}$ & 7.7 & enalaprilum & 11.6 & metoprololum & 8.4 \\
\hline 2 & captoprilum & 4.4 & metoprololum & 9.5 & indapamidum & 7.5 \\
\hline 3 & enalaprilum & 1.9 & indapamidum & 7.7 & atorvastatinum & 5.4 \\
\hline 4 & Ginkgo biloba & 0.7 & Ginkgo biloba & 5.1 & enalaprilum & 4.5 \\
\hline 5 & nicergolinum & 0.5 & simvstatinum & 4.7 & $\begin{array}{l}\text { perindorpilum + } \\
\text { indapamidum }\end{array}$ & 3.5 \\
\hline 6 & metoprololum & 0.5 & captoprilum & 4.1 & bisoprololum & 3.5 \\
\hline 7 & trimetazidinum & 0.3 & trimetazidinum & 3.9 & nebivololum & 3.5 \\
\hline 8 & indapamidum & 0.2 & acidum asparticum $\mathrm{K}+\mathrm{Mg}$ & 2.7 & candesartanum & 3.2 \\
\hline 9 & simvastatinum & 0.1 & diosminum + hesperidinum & 2.5 & $\begin{array}{l}\text { diosminum }+ \\
\text { hesperidinum }\end{array}$ & 3.2 \\
\hline 10 & diosminum + hesperidinum & 0.0 & nicergolinum & 2.5 & trimetazidinum & 3 \\
\hline & Total others & 83.7 & \begin{tabular}{|l|} 
Total others \\
\end{tabular} & 45.7 & Total others & 54.3 \\
\hline
\end{tabular}

\section{Example of details - Statins}

Since their discovery and introduction into the clinical practice in the late 1980s, statins have proved to have a significant role in hyper-cholesterolemia management, in primary and secondary cardiovascular settings. European guidelines have shown that statins reduce the risk of cardiovascular events and mortality, having an important role in secondary prevention and being recommended as the first-line drugs for different cardiovascular diseases [6-8]. In Table IX we can see the marginal presence of statins in 1998, generics of statins in 2007 and the balance in 2017: generic statins $[17,19]$ account for two thirds in volume, almost three quarters in days of treatment and almost half in value.

Table IX

Statins by Product type

\begin{tabular}{|c|c|c|c|c|c|c|c|c|c|}
\hline $\begin{array}{c}\text { ATC4 } \\
\text { PRODUCT TYPE }\end{array}$ & $\begin{array}{c}\text { Units } \\
1998 \\
(000)\end{array}$ & $\begin{array}{l}\text { Units } \\
2007 \\
(000)\end{array}$ & $\begin{array}{l}\text { Units } \\
2017 \\
(000)\end{array}$ & $\begin{array}{l}\text { DOT } \\
1998 \\
(000) \\
\end{array}$ & $\begin{array}{l}\text { DOT } \\
2007 \\
(000)\end{array}$ & $\begin{array}{l}\text { DOT } \\
2017 \\
(000)\end{array}$ & $\begin{array}{c}\text { Values } \\
1998 \\
\text { 000 RON }\end{array}$ & $\begin{array}{c}\text { Values } \\
2007 \\
\text { 000 RON }\end{array}$ & $\begin{array}{c}\text { Values } \\
2017 \\
\text { 000 RON }\end{array}$ \\
\hline C10A1 (STATINS) & 36 & 5,441 & 13,336 & 449 & 110,254 & 388,062 & 952 & 155,088 & 212,392 \\
\hline Original brands & 36 & 970 & 3,526 & 449 & 25,232 & 101,615 & 952 & 58,491 & 111,231 \\
\hline Branded generics & 0 & 4,346 & 9,809 & 0 & 82,759 & 286,446 & 0 & 92,642 & 101,160 \\
\hline Un-branded generics & 0 & 125 & 0 & 0 & 2,262 & 1 & 0 & 3,956 & 1 \\
\hline
\end{tabular}


The penetration rate in all three layers [16] is significant, but it is noticeably higher in the first layer, while in the last layer is clearly below average (Table X). Interesting to note that 2017 shares in all layers are pretty similar in units, days of treatment and value, which is not a very usual situation and shows that statin treatment is homogenous regardless the territorial dimension.

Table X

Statins by Market layer

\begin{tabular}{|c|c|c|c|c|c|c|c|}
\hline $\begin{array}{c}\text { ATC4 } \\
\text { MARKET LAYER }\end{array}$ & Population & $\begin{array}{l}\text { Units } \\
2007\end{array}$ & $\begin{array}{l}\text { Units } \\
2017\end{array}$ & $\begin{array}{l}\text { DOT } \\
2007\end{array}$ & $\begin{array}{l}\text { DOT } \\
2017\end{array}$ & $\begin{array}{c}\text { Values } \\
2007\end{array}$ & $\begin{array}{c}\text { Values } \\
2017 \\
\end{array}$ \\
\hline C10A1 (STATINS) & $100.0 \%$ & $100.0 \%$ & $100.0 \%$ & $100.0 \%$ & $100.0 \%$ & $100.0 \%$ & $100.0 \%$ \\
\hline Important cities & $19.3 \%$ & $51.1 \%$ & $41.1 \%$ & $51.9 \%$ & $41.2 \%$ & $52.8 \%$ & $43.7 \%$ \\
\hline Medium-size cities & $16.1 \%$ & $23.4 \%$ & $25.4 \%$ & $23.1 \%$ & $25.2 \%$ & $23.4 \%$ & $26.0 \%$ \\
\hline Small cities \& villages & $64.6 \%$ & $25.5 \%$ & $33.6 \%$ & $24.9 \%$ & $33.5 \%$ & $23.8 \%$ & $30.3 \%$ \\
\hline
\end{tabular}

Table XI

Statins - Top 5 INNs

\begin{tabular}{|c|l|c|l|c|l|c|}
\hline \multirow{2}{*}{ Rank } & \multicolumn{2}{|c|}{$\mathbf{1 9 9 8}$} & \multicolumn{2}{c|}{$\mathbf{2 0 0 7}$} & \multicolumn{2}{c|}{$\mathbf{2 0 1 7}$} \\
\cline { 2 - 7 } & \multicolumn{1}{|c|}{ INN } & \% volume & INN & \% volume & \multicolumn{1}{c|}{ INN } & \% volume \\
\hline 1 & simvastatinum & 91.6 & simvastatinum & 81.9 & atorvastatinum & 54.72 \\
\hline 2 & pravastatinum & 7.3 & atorvastatinum & 10.9 & rosuvastatinum & 27.72 \\
\hline 3 & lovastatinum & 0.7 & rosuvastatinum & 4.7 & simvastatinum & 16.55 \\
\hline 4 & fluvastatinum & 0.3 & fluvastatinum & 1.3 & pravastatinum & 0.44 \\
\hline 5 & atorvastatinum & 0.1 & lovastatinum & 1.2 & lovastatinum & 0.43 \\
\hline & Total Others & $\mathbf{0 . 0}$ & Total Others & $\mathbf{0 . 0}$ & Total Others & $\mathbf{0 . 1}$ \\
\hline
\end{tabular}

It can be observed that the Top 5 INNs [20] are almost the same in two decades but their share has changed significantly due to a number of reasons, as therapeutic experience, price, availability etc. (Table XI).

From Table XI, the most commonly prescribed statin in the Romanian medical practice is simvastatinum, the only lipid-lowering agent mentioned on the current version of WHO Model List of Essential Medicines, since 2010 (the $21^{\text {th }}$ list) $[13,15]$. Until then, HMG-CoA reductase inhibitors were described as "a family of potent and effective lipid-lowering drugs with a good tolerability profile" but "since no single drug has been shown to be significantly more effective or less expensive than others in the group, none is included in the Model List; the choice for of drug for use in patients at highest risk should be decided at the national level"; therefore, no substance was present on the core list [12].

\section{Conclusions}

Taking into account all measures of analysis: units, DOT and values, the cardiovascular market has grown significantly over the last twenty years.

An increased number of patients has been treated for cardiovascular diseases which represents a positive development, judging the fact that the leading cause of death in Romania/a significant proportion of deaths and disability in Romania, as well as in other European countries, is represented/caused by cardiovascular diseases.

The results of our study reveals that by therapeutic groups, the biggest share in days of treatment belongs to C9 (inhibitors of the renin-angiotensin system), followed at certain distance by C10 (anti-atheroma agents and lipid regulators), C1 (cardiac therapy), C7 (beta-blocking agents), C8 (calcium antagonists) and C3 (diuretics).

\section{Acknowledgement}

This paper was financially supported by "Carol Davila" University of Medicine and Pharmacy through Contract no. CNFIS-FDI-2019-0534 (MEDEX-II) funded by the Ministry of National Education of Romania, from the Institutional Development Fund for Public Universities - FDI 2019.

\section{References}

1. Dorobanțu M, Bădilă E, Ghiorghe S, Darabont R, Olteanu M, Flondor P, Total cardiovascular risk estimation in Romania. Data from the SEPHAR study. Rom J Intern Med., 2008; 46 (1): 29-37.

2. Kotseva K, The EUROASPIRE surveys: lessons learned in cardiovascular disease prevention. Cardiovasc Diagn Ther., 2017; 7(6): 633-639.

3. Kotseva K, Wood D, De Bacquer D, Pyorola K, Keil U, EUROASPIRE III: a survey on the lifestyle, risk factors and use of cardioprotective drug therapies in coronary patients from 22 European countries. Eur $J$ Cardiovasc Prevent Rehabil., 2009; 16: 121-137.

4. Kotseva K, Wood D, De Bacquer D, De Backer G, Rydén L, EUROASPIRE IV: A European Society of Cardiology survey on the lifestyle, risk factor and therapeutic management of coronary patients from 24 European countries. Eur J Prev Cardiol., 2016; 23(6): 636-648.

5. Lin I, Sung J, Sanchez RJ, Mallya UG, Friedman M, Panaccio M, Koren A, Neumann P, Menzin J, 
Patterns of statin use in a real-world population of patients at high cardiovascular risk. J Manag Care Spec Pharm., 2016; 22(6): 685-698.

6. Perk J, Backer G, Gohlke H, Graham I, Reiner J, Verschuren M, European Guidelines on cardiovascular disease prevention in clinical practice (version 2012): The fifth Joint Task Force of the European Society of Cardiology and Other Societies on Cardiovascular Disease Prevention in Clinical Practice (constituted by representatives of nine societies and by invited experts). Eur Heart J., 2012; 33(13): 1635-1701.

7. Piepoli MF, Hoes AW, Agewall S, Albus C, Brotons C, Catapano AL, Cooney MT, European Guidelines on cardiovascular disease prevention in clinical practice: The Sixth Joint Task Force of the European Society of Cardiology and Other Societies on Cardiovascular Disease Prevention in Clinical Practice (constituted by representatives of 10 societies and by invited experts). Eur Heart J., 2016; 37(29): 2315-2381.

8. Parepa IR, Suceveanu AI, Mazilu L, Mohamed A, Niţă D, Tuţă LA, Preventing cardiac complications after non-cardiac non-vascular surgery by using perioperative statin therapy - A prospective study in Constanta county, Romania. Farmacia, 2017; 65(1): 120-124.
9. Popovici I, Lupuleasa D, Pharmaceutical technology, vol 1-3, Ed. Polirom, Bucharest, 2017. (available in Romanian)

10. Țica OA, Țica O, Antal L, Hatos A, Popescu MI, Stoian AP, Bratu OG, Găman MA, Pițuru SM, Diaconu CC, Modern oral anticoagulant treatment in patients with atrial fibrillation and heart failure: Insights from the clinical practice. Farmacia, 2018; 66(6): 972-976.

11. xxx Pharma and Hospital Report - Cegedim

12. $x x x$ World Health Organization. WHO Model List of Essential Medicines - 12 ${ }^{\text {th }}$ List, 2002.

13. xxx World Health Organization. WHO Model List of Essential Medicines - 16 ${ }^{\text {th }}$ List, 2010.

14. xxx World Health Organization. Noncommunicable diseases country profiles 2018. Geneva: World Health Organization, 2018.

15. xxx World Health Organization. WHO Model List of Essential Medicines - 21 ${ }^{\text {st }}$ List, 2019.

16. xxx Romanian statistical year-book, 2017: 63-66. (available in Romanian)

17. xxx Ministry of Health Order 368/2017, 2017. (available in Romanian)

18. xxx www.whocc.no (WHO Collaborating Centre for Drug Statistics Methodology).

19. xxx www.ms.ro (Ministry of Health).

20. xxx www.anm.ro (National Agency for Medicines and Medical Devices). 